Journal of Law \& Social Studies (JLSS)

Volume 3, Issue 2, pp 124-132

www.advancelrf.org

\title{
Justice Delayed or Denied: The Myth of Justice in Pakistan
}

\author{
Dr. Muhammad Bilal \\ LLM (UK) PhD (UK) \\ Assistant Professor, Gillani Law College, \\ Bahauddin Zakariya University, Multan, Pakistan \\ Email: mbilal@bzu.edu.pk \\ Farqaleet Khokhar \\ Super Senior, LLB (Hons) \\ Gillani Law College, \\ Bahauddin Zakariya University, Multan, Pakistan \\ Email: farqaleet.khokhar@gmail.com
}

\begin{abstract}
Justice in Pakistan has become a myth and an unachievable tool. In Pakistan only the concept of delayed justice exists as the delayed justice which actually is a denied justice. The main aim of this paper is to analyze the factor causing delay in justice. There are several reasons for delayed justice including complex procedures, old and ineffective laws, attitude of judges and lawyers, and the backlog of the pending cases in the superior as well as lower judiciary of Pakistan. The article highlights the significant causes of delayed justice and elucidates how justice can be revived in Pakistan. The study investigates how the stock of pending cases is increasing day by day causing denial of justice. This article also discusses the impacts of delayed justice on society and especially on litigants. In the end this article deliberates some recommendations for revival of justice in Pakistan.
\end{abstract}

Keywords: Delayed Justice, Hurried Justice, Backlog of pending cases, psychological impacts, Revival of Justice.

\section{Introduction}

Justice has a significant importance in the life of an individual and justice is an essence of the civilized society. But delayed justice causes anarchy in society. The "Judiciary of Pakistan" has trend of denial of justice by delaying it so due to such attitude the society plunges into the radicalism, terrorism and sectarian conflicts. Delayed justice has social impact as well as it also has psychological impact on the litigant. Judiciary became no more hope for the people and due to delayed justice, the trust of people on court had been lost. This paper analytically investigates the causes of delaying justice in Pakistan. For that the research at first instance discusses the demand of justice for society, the importance of justice and the concept of justice to highlight the gravity of delayed justice and to ensure that the delayed justice is the denial of justice. This paper scrutinizes that corruption and transfer of judges, unreasonable and maxim adjournments, complex procedural technicalities, judicial delays and intricacy of old laws has become the main factor of delayed justice. The stock of pending cases increasing day by day makes the delayed justice evident up to the extent of denial of justice.

This research piece examines that Pakistan Judiciary has been failed to provide the expeditious justice due to that the dissatisfaction of people towards the judicial system of Pakistan has been increased and it is fact the delayed justice is impacting the life of litigant and due to delayed justice litigant suffers financial, mental and psychological trauma. In the end this research snippet describes how justice can be revived in Pakistan and which measures and obligations 
should be followed to overcome the problem of delayed justice in Pakistan and how the infrastructure and judicial system of Pakistan can be enhanced and upgraded. The paper culminates into a reasonable conclusion.

\section{Literature Review}

In Pakistan justice is delayed due to several reasons including judicial and procedural delays. The criminal and civil suits in Pakistan are governed in the light of "Code of Criminal Procedure, 1898" (Cr.P.C) and "Code of Civil Procedure, 1908" (C.P.C.) in both codes there is detail of the legal framework but actually such legal framework is slow and complex due to which the justice is delayed not only justice is delayed but the money, time as well as the talent is wasted (Chowdhury, 2004). Justice is the basic fundamental right of each Pakistani because the "Constitution of the Islamic Republic of Pakistan, 1973" under Article 37(d) ensures the speedy justice to the Pakistani (Sherwani, 2006). Easy and expedient resolution of the conflict can be done by the general and swift laws because irrational and complex laws cause delay and interrupt the interest of parties to the cases (C. R. van Rhee, 2020).

According to the research of "F.S.Khan," Pakistani courts require the continuous visits of the suit's parties and normally for decision of any conflict a defendant makes 72 visits to the courts and a decision of case costs nearly 0.2 to 0.3 million upon such party. Continuous visits to courts not only cause the financial crisis but it can also have psychological impact on the suit's parties.

Judges are the backbone of the judiciary and in Pakistan the no professional attitude. Judges perform their function only for salary but not for justice (Sherwani, 2006). Due to such behavior the backlog of the pending cases is increasing day by day and denying justice. A report "Study of informal justice system in Pakistan" estimated that Pakistani courts need " 15 years" to try the backlog of pending cases and there will be a condition that in those " 15 years" no new case should be instituted in the courts. Normally Pakistani courts take " 25 years" to decide a case and " 5 years" more to execute the decree (Khan, 2004). Due to such behavior of courts the cases are accruing day by day. In January 2021 the numbers of pending cases were "2162042" (Statement of cases Pending, January 2021). But according to "Consolidate statement of pending cases, pendency, institution and disposal of cases during the period August 2021 " the Pakistani Judiciary has a backlog of "2,177,527" cases in August So from January to August 15485 cases added to the stock of pending cases. The cases are accumulating day by day consequently, delaying and denying justice.

For expeditious justice Pakistani judicial system needs reforms to insure the rule of law. The Pakistani judicial system must update the old complex laws (Salauddin, 2016). The number of courts and judges should be increased (Pratiksha Baxi, 2008). Budget of the Pakistani courts must be increased (Nasir, I, 2018). The Pakistani Judicial system must introduce advanced technology (Malik, A, 2019) for revival of expeditious justice in Pakistan.

\section{Justice as a Challenging Demand}

The foundation of a civilized society is always rooted in justice. Justice distinguishes the rights as well as responsibilities of the citizenry. (Rawls, 1999) In old times, "reasonable conduct and morality" was recognized as justice. In "Roman laws" justice was referred to as the "natural or positive law". "Aristotle" in "Book V" of "Nicomachean Ethics" states that justice is a genus of disposition that insists any humankind to act judiciously and justly. So, justice is the foremost character of an individual that not only is appreciated by humans but is also admired by the whole society. It is also admitted that the whole society admits the administration of justice not only in their individual life but also in their communal life.

The coordination and coherence, reconciliation, safety and decent governance in the society are ensured by justice. In Sardar Attique ur Rehman $v$ The State and ors, Peshawar High Court of Pakistan stated that "Justice should not only be done but should be manifestly seen to be done." Further in Ishtiaq Ahmed v Hon'ble Competent Authority through Registrar, SCP stated that in constitutional democracy justice is the fundamental requisite of rule of law. Court further stated that justice is the benchmark of a cultured society. The court further conceded that the "fair trial, justice and due process" are the basic inherent right of a man (2016 SCMR 943). The decree of the court was embellished with the social norms although norms in words look motivational but when it comes to implementation it becomes difficult to achieve them and sustain the existence of such norms in society. Justice is a benchmark but how it is sustained and attained in a society is a bit challenging. 
In case Suo Motu Case No. 4 of 2010, Court sarcastically referred to a piece of "Khalil Gebran" and criticized the nation which lacks the justice or expeditious justice or demands partial justice. Court stated that "Pity the nation that demands justice for all.... but is agitated when justice hurts its political loyalty." Pity the nation that clamors for equality before law.... but has selective justice close to its heart." (PLD 2012 SC 553)

Here's a question that arises in a layman's mind: which class of nation has been criticized as the whole nation demands and clamors for justice and equity before law and nation never felt anxiety when a political loyalty is hurt. It has always been the courts that give decisions. These decisions could have an element of partial and impartial justice then how selective justice is close to the heart of the nation. The unjust, biased, extra constitutional, less advantageous, less rationally, less moral and foremost of all delayed decisions are made by the institutions that work for the implementation of justice, not by the nation.

There are many cases in the "Judicial and Constitutional History of Pakistan" in which so called justice had been done by courts and such partial justice has been badly criticized and such cases are strain on judicial history of Pakistan case like "Federation of Pakistan v Maulvi Tamizuddin Khan (PLD 1955 F.C. 240), Nusrat Bhutto v Chief of Army Staff (PLD 1977 S.C. 657) and Zafar Ali Shah v General Pervaiz Musharraf (PLD 2000 S.C. 869)" and many more.

\section{Delayed Justice}

"Dispensation of justice" is the prime essence of a civilized community. Speedy Justice and swift disposal of the conflicts and redressal of grievances of accused are the paramount elements of an effective administration of justice. (2021 YLR 1415) It is the duty of the court to hear the case with full ears and patience and not make an excuse for delaying the trial on the grounds that court has rush of work. The court must perform the divine duty of accessing speedy justice to the people. (PLD 2020 Sindh 68) In MFMY Industries Ltd. v. Federation of Pakistan, Court stated that

"Court cannot, legally and morally, take excuse of 'rush of work'. Not a single decision of a court of law should reflect that it was not a 'decision' but an attempt to earn 'numbers/units' or to lessen the number of cases entrusted to it for disposal 'according to law'. Thin line between two known legal maxims i.e. 'justice delayed is justice denied' and 'justice hurried is justice buried' must always be appreciated by every single court." (2015 SCMR 1549)

Court has referred to the both opposing legal principles together "Justice delayed is justice denied" and "justice hurried is justice buried" and considered that there is a thin line between these two principles although court had not described what that thin line means. Both maxims are contradictory and are not only poles apart, but both exist on extremes. The court must maintain balance while appreciating these maxims because these legal principles have the contradiction in their nature, and both are much desired features of the legal system as aggrieved party desires for hurried justice while frivolous litigant desires for delayed and denied justice. Hurried justice can lack the thorough analysis and inspection of the case while delayed justice infringes the fundamental human rights of justice. So there always remains a contradiction between the time and the quality and that intensely exists in Pakistani Courts.

Delayed justice generates an assumption that either justice has been done or not. "Unreasonable delay in justice" breaches freedom as well as it also threatens the well-being of an individual. (Alan. L., 1968) Delayed justice infringes the right of life and liberty that are guaranteed by Constitution of Pakistan, 1973. The delaying justice in Pakistan is of the most disturbing matter because a fundamental right is at an issue. The assurance to expeditious justice is foremost for the survival of democracy. It is ironic that a country like Pakistan which is a democratic country having a reasonable legal system has the least execution of justice. It is very odd that such an imbalance is not fascinated with any concern.

It is factual that there is need of proper and reasonable time for decreeing a case and no case can be decreed instantly. Court needs a proper time to inspect the case. So usually reference to the term speedy justice means the fair expeditious not hurried and hasted. Delayed Justice forms two types of harms: in criminal cases, the accused suffers prolonged detention before trial and anxiety due the allegations made by the public. (People v. Rehman)

It cannot be neglected that for the final judgment of any lawsuit court requires time to investigate the matter, inspection of evidences, and perusal of record, and to establish relation or privity between the suit parties and to clarify the 
question in conflict after all these processes court become able to verdict a case (World Bank, 2006). Court has to follow the procedure and the basic concepts of "law, equity and justice." (Pathon, 1973) Any verdict given without following the essence can be full of flaws. Although the court should have to follow the basic procedures and laws but lengthy, complex procedures having many imperfections, passive and subjective procedural technicalities can result in delayed justice and the court cannot hide itself that much of time had been wasted in following procedure and finding proper remedy for the final disposal.

Along with the "complexity of procedures" the "intricacy of the lawsuit" plays a vital role in delaying justice as the complex lawsuit requires more time for its preparation. And in the light of jurisprudence the "intricacy of the lawsuit" has an adverse correlation with the speed for decreeing a lawsuit (Miani, 2009). It is also a fact that a complex case needs a lot of time in court, so the judges and justices are suggested to verdict such cases with full attention and care. Haste in deciding such cases can cause errors as the speedy judgments in such cases can never meet the criteria of justice and equity. (Pekkanen, 2011) Although for deciding complex cases the courts are also required to maintain a balance between delayed and hurried justice. The "maximum adjournments" are not acceptable on the ground that the case is complex, and court requires time and time to decide the matter. The reasonable time to decide a case is the right of court but such reasonable time should not exceed its limits.

Pakistani courts in their judgments very often describe and define the "concept of justice" and concede that courts are the only institutions that are working for the "propagation of natural justice and expeditious justice." The court very truly states that justice is hope, delayed justice is denied justice, hurried justice is buried justice, justice is fundamental principle of a civilized society, justice via "fair trial and due process, expeditious justice," part of constitution and many more. But justice is the most eminent and most violated legitimate principle in Pakistan. Justice is widely described in the theories, hypothetical fables, ritualistic occurrences, on the doorstep of the courtroom and the constitutional, ordinary, partly and final decrees of courts. Justice can be scrutinized by the practical application of it and practically in Pakistan it is not more than a mere myth and it can be evident from millions of backlog cases pending in Pakistani Courts.

\section{Significant Causes of Delayed Justice}

Although it is complex to mention a few causes of delaying justice, it is true that there are many factors that are causing delayed justice in Pakistan. Delay is not a new concept and it adds fuel to grievances of the aggrieved party. Delayed justice promotes "the crime rate, violation of rights, anxiety, extortion, agitation, insecurity, corruption, abuse, defamation, torture and harassment by police as well as religious and denominational conflicts."

Foremost reason for delaying justice is fault in the "judicial system." The fault in judicial system arises when the number of cases filed are much more than the number of judges hearing such cases. "Insufficient court administration" including the "inadequate staff, lack of budget and insufficient courtroom is also causing of delaying justice." (Banfield \& Anderson, 1968)

The administration of justice is necessary but in Pakistani administration of justice has reasons for delaying justice. "Laden dockets, backlog of pending cases, procedural and judicial delays and unfair postponements of cases" are significant obstacles in delaying justice in Pakistan. (Chaudhry, 2011) The judicial delays include "transfer of cases, arbitrary and excessive adjournments, transfer and corruption of judges as well as no appearance of the parties of suits and their advocates in the courtroom." While procedural delays occur due to the existence of long and complex legal procedures and intricate procedural technicalities. (International Crisis Group, 2008)

Judges are the backbone of the courts and they work for the dispensation of justice but in Pakistan the non-professional attitude is prevailing (Sherwani, 2006). Further the "transfer of judges" from one court to another also delays justice (Alam, 2010). Above all the lawyers in Pakistan mould the procedures for getting "unreasonable relief" and such reliefs are granted by the judges because the judges are bound by laws. Due to this the judges are unable to take the action against non-attending of parties to suits (Shah, R \& Ahmad, J). Many judges are not well-trained (Van Rhee, 2004). So, they fail to compel the lawyers to dispose of the cases in time and according to rules prescribed by law (Adler, F, \& Conference, 1982).

Usually in the criminal courts much of time is utilized in determining the fact in issue. Consequently, the court loses much of important evidence and sometimes the facts in issues before the court are not clearly depicted, many ambiguities are present in the plaint that may also become cause of delay. Much time in criminal cases is wasted in delaying investigations by police as well. (P McClellan, 2020) 


\section{Backlog of Cases and Delayed or Denied Justice}

First, it is important to describe the concept of the timelines and then to describe the concept of delay. The "timelines" is a subjective term and it is defined differently by scholars, legal academics, and staff of the court, administrators, justices and judges and parties of the suit (Sourdin, 2013). "Timelines" refer to the standard time in which the final decree might be made. And the standard time for resolution of any dispute in the lower court is not more than "six months." (Local Court Time Standards, 2012) In this context any cases if it is decreed after six months will be considered as a delayed decree.

Pakistani courts have a bundle of pending cases. Some of them were instituted " 50 years" before but had not been decreed up till now. In 2008 a report on "Study of informal justice system in Pakistan" published in Pakistan the report stated that delaying justice in Pakistan is not a new utterance. The report estimated that Pakistan courts need more than " 15 years" to try the huge stock of pending cases. The Pakistani Court usually takes " 25 years" to decree a case and for execution of that decree " 5 years" more are required. (International Crisis Group, 2008) it is also estimated that on an average a party to suit makes " 72 visits" to court as well as spends nearly " 0.2 to 0.3 million" for getting justice. (Khan, 2004)

"Consolidate statement of pending cases, pendency, institution and disposal of cases during the period August 2021" affirmed that the Pakistani Judiciary has a backlog of "2,177,527 cases. 54043 cases are pending before Superior Courts including SCP and Federal Shariat Court while 350495 are pending in of High Courts of all provinces including Islamabad High Court (IHC) and the district judiciary of Pakistan has a backlog of 1,773,171 cases." The numbers of cases pending before each court are illustrated below (Consolidate statement, August 2021) accessed from http://licp.gov.pk/nljcp/assets/dist/news_pdf/courts.pdf

Pendency of cases before Superior Courts

\begin{tabular}{|l|l|}
\hline Name of Superior Courts & Number of pending cases \\
\hline Supreme Court of Pakistan & 53686 \\
\hline Federal Shariat Court & 175 \\
\hline Total & 53,861 \\
\hline
\end{tabular}

Pendency of cases before High Courts

\begin{tabular}{|l|l|}
\hline Name of High Courts & Number of pending cases \\
\hline Lahore High Court & 197907 \\
\hline Sindh High Court & 86679 \\
\hline Bulochistan High Court & 4538 \\
\hline Islamabad High Court & 16858 \\
\hline Peshawar High Court & 44513 \\
\hline Total & 350495 \\
\hline
\end{tabular}

Pendency of cases before lower courts

\begin{tabular}{|l|l|}
\hline Name of Lower Courts & Number of pending cases \\
\hline District Courts of Punjab & 1336315 \\
\hline District Courts of Sindh & 117938 \\
\hline District Courts of Khyber Pakhtunkhawa & 249013 \\
\hline District Courts of Bulochistan & 17306 \\
\hline District Courts of Islamabad & 52599 \\
\hline Total & $1,773,171$ \\
\hline
\end{tabular}

Grand total number cases pending in the Judiciary of Pakistan

\begin{tabular}{|l|l|}
\hline Total number of cases pending in superior judiciary & 53,861 \\
\hline $\begin{array}{l}\text { Total number of cases pending in High Courts and } \\
\text { IHC }\end{array}$ & 350495 \\
\hline number of cases pending in District judiciary and IDC & $1,773,171$ \\
\hline Grand total & $2,177,527$ \\
\hline
\end{tabular}


It is impossible to ensure the administration of justice while having a stock of cases pending before all courts of Pakistan and the number of pendency is increasing day by day. Similar report published in January depicted that the Pakistani Judiciary had a "backlog of 2162042 cases including Superior courts had a backlog of 46873, High Courts of Pakistan had 331343 while district judiciary of Pakistan had 1783826 cases pending." (Statement of cases Pending, January 2021)

Means from January to August " 15485 " cases are added in the already existing backlog of cases. Consequently, it can also be admitted that Pakistan has a trend of denial of justice by delaying it. The previous backlog of cases and constant institution of new cases shows impracticability of justice and the cases pending from decades and had not been decided yet also encourages the denial of justice.

\section{Impact of Delayed Justice on Litigants}

Delayed Justice is an obstacle for development of civilized society. It hinders the "socio-economic growth" of the society. It discourages the foreign investors and also affects foreign investment. The delayed justice affects the trade and business with multinational companies and foreign governments. (Owais M., Volume 03) Delayed Justice has undoubtedly affected the state and its affairs more than this delayed justice affects the litigants or parties of suits. The delayed justice has a very lethal impact not only on the lives of parties of suits, but it also upsets the litigant psychologically especially the aggrieved party is much affected with delayed justice.

Failure to deliver timely justice is a violation of "fundamental rights" and delayed justice by affecting the lives of suit parties further violates "fundamental human rights." The negative impact of delayed justice increases when delay occurs in disposition of matters involving "fundamental rights." In short delay in justice constitutes other supplementary infringements (Angelo B. Dube, 2010).

Delayed Justice psychological effects the litigants as the moving of parties of suit from one court to another, change of judges or recording of the evidence again and again that make the parties psychological uncomfortable and delaying strategies of lawyers. In this way litigants find themselves in a vicious circle. So, delaying justice is not only substantially exhausting but also emotionally frustrating. (Sourdin, Tania and Burstyner, Naomi, 2016)

In MFMY Industries Ltd. v. Federation of Pakistan, Court affirmed that

"Court is not a mere mixture of construction material but in its literal sense is a 'hope' where complainant or plaintiff (as the case may be) comes with a hope of justice. Court must always act in such a manner so that every single decision thereof should satisfy its literal meaning i.e. 'a place where justice is done/dispensed'. Litigants should never be given a 'disposal of their approaches' but a 'decision by a Court of law."

So, when a court is hope for the litigants then delaying litigations can also hurt the hope of the litigants. A person alleged in any crime the society considered him a convicted although at that time he had not been convicted by the court. But if the court with undue delay affirmed his acquittal the loss to his reputation, mental agony and mental teasing of that person by society cannot be compensated. The person goes to court with a hope to get remedy and when he faces repeated adjournments then undoubtedly, he has to be encountered with "psychological, physical and financial trauma."

\section{Recommendations for Revival of Justice}

Justice is fundamental principle of Islam as in Quran in Surah "Al Imran verse 108" Allah stated that "Allah wants no injustice to the world." In Surah"Al Araaf verse 181" it is stated that "We created a community which guides by truth and by it establishes justice."

"Last Prophet Muhammad (S.A.W)" had never compromised on justice. In the light of hadith, it can be elaborated that in Islamic law there is no concept of delaying justice because the decisions made by "the Prophet and his Caliphs" were unbiased and based on fundamental principles of humanity. Once a lady of a very rich and reputable tribe named "Banu-Makhzum" was found guilty of theft. "The plea of forgiveness" was made to the "Prophet (S.A.W)". But the prophet stated that many nations in the past were destroyed because their laws punish only the poor and forgive the 
rich. The "Prophet (S.A.W)" by swearing upon God further stated that "if his own daughter would be found guilty with the charge of theft then he would definitely cut her hand." Such examples of Islamic justice system are the sources of light that can at first instance be the cause of speedy and impartial justice as well as can play a role in balancing the society.

The most important feature of human rights is expeditious justice and it is the duty of Pakistan to provide expeditious justice to the citizenry. Speedy justice is the constitutional right of all Pakistanis as article 37(d) of Constitution of Pakistan demands the promotion of justice as well as "ensure inexpensive and expeditious justice." Expeditious justice is very important and is an essence of an enlightened and distinct legal system because the unreasonable delays threaten the interests of litigants.

In Pakistan, the existing procedural laws are very old and less advantageous as the "Cr.P.C. and C.P.C" are 118 and 108 years old respectively while the age of "Rules of Court Managements" is nearly 80 years old. These laws were made by the colonial masters and are now ineffective in their nature. For expeditious justice there is a need to amend such laws and introduce greater efficiency in them. There is a need to update such laws according to the existing realities. (Salauddin, 2016) There is a need for judicial reforms. These reforms must include the introduction of such a legal system that ensures expeditious investigation of any crime. For such investigations should be completed within the period of one to two to months. Because delayed investigations are one of the causes of delayed justice. Judicial reforms must ensure the presence of simple procedures and simpler laws as complex procedures and laws means delayed justice.

The Pakistani Constitution guarantees the rights of the citizenry and in case of breach of their rights the citizen can approach the proper court for remedy and justice. This is usually misused by the "habitual litigants" initializing the "frivolous litigations" against the innocents. Such "frivolous litigants" not only violate the rights of innocents but also wastes the time of court as well as increase the backlog of cases. In such cases the court must award exemplary fiscal punishments to avoid the institution of frivolous litigation.

It is usually stated that increasing the "number of judges" cannot help in dealing with a backlog of pending cases (Pratiksha Baxi, 2008). Although it is not true because increasing the number of judges will be an additional strength to the existing judiciary. For revival of expeditious justice, there is a need to "increase the number of courts" in Pakistan that can also help in adjudication of a backlog of cases. The areas or cities that are remote and rural should be given preference so that the people of these areas should get remedy within minimum distance and least expenses.

Pakistan spends nearly 0.02 per cent of its budget on management and infrastructure of the judiciary of Pakistan. Pakistan spends nearly "1.81 out of 900 billion of its budgets" on judiciary (Nasir, I, 2018). It is astonishing that a country that has a faith on justice spends so little for dispensation of justice. Moreover, from the last few years granted funds had not been utilized for the advancement of infrastructure of Pakistani court. The increase in the number of courts and judges will be effective in case the budget of the court will also be increased for the development, upgrading and enhancement of infrastructure of court as well as to build more courtroom and to increase the staff and officers of the judiciary.

In this postmodern century there is a need to introduce advanced technology in the court and the court should properly start to provide expeditious justice via "e-courts". The "e-court system" has been used by the Supreme Court of Pakistan (Malik, A, 2019). However, the "e-court" system should be introduced to lower judiciary as well. Such a system should be properly executed so that expeditious justice can be revived. The commencement of court proceedings, conferences via videos, online institution of petitions and plea as well as online filing of cases can enhance the justice in Pakistan. The Pakistan judiciary must utilize and introduce the "Tele Law Services" and "Pro Bono app."

\section{Conclusion}

Since delayed justice is a bad trend, it seems worrisome that Pakistan is deficient in prevailing expeditious justice. Delayed justice can never empower or contribute to the growth of society. Delayed justice infringes the fundamental human rights and it is a fact where there is delayed justice there is no rule of law. The complex judicial system, intricacy in procedures of Pakistan, the backlog of cases and burden of cases on Pakistani Judiciary are causes of failure providing speedy justice. This flaw of delayed justice is to be removed in this way: "amendment in the laws, upgrading infrastructure and management of court, introduction of modern technology including e-court, increasing number of courts and judges" can revive the justice system in Pakistan along with all these developments the "budget 
of courts" must have to be increased. It is the need of hour to revive justice in Pakistan otherwise the delayed justice will hinder the materialization of a wish to have a speedy, approachable and effective justice in Pakistan.

\section{References}

Angelo B. Dube, Assessment Study on Delayed Justice Delivery, p 3, Final Report July 2010

Alam, M. (2010). Problems of delay and backlog cases. The Daily Star

Adler, J. W., Felstiner, W. F., \& Conference, S. M. I. f. C. J. (1982). The pace of litigation: Conference proceedings: Rand.

Banfield, L., \& Anderson, C. D. (1968). Continuances in the Cook County Criminal Courts. The University of Chicago Law Review, 35(2), 259-316.

Chaudhry, I. M. (2011). Concluding speech. Paper presented at the National judicial conference 2011, Islamabad.

Chowdhury, M. M. R. (2004). A Study on Delay in the Disposal of Civil Litigation: Bangladesh Perspective. The International Journal of Social Sciences, 14, 27-35.

Consolidate statement showing pendency, institution and disposal of cases during the period 1- 31st August 2021 in the Supreme Court of Pakistan, Federal Shariat Court, High Courts and District Judiciary http://ljcp.gov.pk/nljcp/assets/dist/news_pdf/courts.pdf

G.W. Paton, A Textbook of Jurisprudence, Fourth Edition, Oxford University Press, 1973

Ishtiaq Ahmed v Hon'ble Competent Authority through Registrar, Supreme Court of Pakistan 2016 S C M R 943

International Crisis Group. (2008). Reforming the judiciary in Pakistan Asia Report $N^{\circ} 160$ Islamabad; Brussels: International Crisis Group.

International Crisis Group. (2008). Reforming the judiciary in Pakistan Asia Report N 160 Islamabad; Brussels: International Crisis Group

Khan, F. S. (2004). Quest for justice: Judicial system in Pakistan. Islamabad: The Network Publications.

Muhammad Zada v The State through Additional Advocate General and ors (2021 YLR 1415)

Mrs. Nasima Yousuf through Special Lawful Attorney v Tehseen Abass Gilgiti and others PLD 2020 Sindh 68

MFMY Industries Ltd. v. Federation of Pakistan 2015 SCMR 1549

Miani, M., Conrad, H., \& Lynch, P. (2009). The right to a fair hearing and access to justice: Australia's obligations: Senate legal and constitutional affairs committee: inquiry into australia's judicial system, the role of judges and access to justice

Malik Asad, In a first, SC to use-court system, Dawn, May 24, 2019 https://www.dawn.com/news/1484248

Nasir Iqbal, 8pc Increase in Supreme Court Budget proposed in Budget 2018-19, Dawn, April 28, 2018 https://www.dawn.com/news/1404333

New South Wales Government, Local Court Time Standards (14 March 2012) <http://www.localcourt.justice.nsw.gov.au/localcourts/timestandards_pracproc.html>.

Owais M. Bari, Delayed Justice and its impact on Human Rights in Pakistan, Volume 3, University College Lahore Human Rights Review https://humanrightsreviewpakistan.wordpress.com/volume-iii/delayed-justice-andits-impact-on-human-rights-in-pakistan/\#_ftn1

P McClellan, 'The Australian Justice System in 2020' (2009) 9(2) Judicial Review 179 and P McClellan, 'ADR - An Introduction' (Speech delivered at the Chinese National Judges' Conference, Kunming, April 2008) citing A Mason, 'The Future of Adversarial Justice' (Paper presented at the 17th Australasian Institute of Judicial Administration Annual Conference, 6-8 August 1999).

People v. Rehman, 253 Adv. Cal. App. 117 
Pratiksha Baxi, Access to Justice and Rule-of (Good) Law: The Cunning of Judicial Reform in India, 2 Indian Journal of Human Development 10 (2008), https://www.researchgate.net/publication/228914213_Access_to_Justice_and_Ruleof_Good_Law_The_ Cunning_of_Judicial_Reform_in_India (last visited Jun 3, 2020).

Pekkanen, P. (2011). Delay reduction in courts of justice; possibilities and challenges of process improvement in professional public organizations. Lappeenranta University of Technology, Lappeenranta, Finland.

Rawls, J. (1999), “A Theory of Justice,” Revised edition, Harvard University Press, Cambridge. P 3

Sourdin, Tania and Burstyner, Naomi, Justice Delayed is Justice Denied (January 24, 2016). Available at SSRN: https://ssrn.com/abstract=2721531 or http://dx.doi.org/10.2139/ssrn.2721531

Sardar Attique ur Rehman v The State and others 2021 P Cr. L J 1216

Salauddin Ahmad, Justice delayed is Justice denied, Dawn, 2016, https://www.dawn.com/news/1303235

Sherwani, Z. A. K. (2006). Cash flow management system and court automation. Paper presented at the International judicial conference, Islamabad.

Suo Motu Case No. 4 of 2010 PLD 2012 SC 553

Shah, R. U., \& Ahmad, J. Delayed Judicial Processes in Civil Courts and Peacemaking in Pakistan

Statement of cases Pending in Pakistan January 2021 http://ljcp.gov.pk/nljcp/assets/dist/news_pdf/courts.pdf

T Sourdin, The Timeliness Project: Background Report (Australian Centre for Justice Innovation, 2013)

The Right to a Speedy Trial, Alan L. Schneider, Stanford Law Review, Vol. 20, No. 3 (Feb., 1968), pp. 476-503

Van Rhee, C. H. (2004). The law's delay: essays on undue delay in civil litigation (Vol. 47): Intersentia nv.

Van Rhee, C. R. (2020). Judicial Case Management and Loyal Cooperation: Towards Harmonized European Rules of Civil Procedure Courts in Evolving Societies (pp. 168-202): Brill Nijhoff.

World Bank. (2006). Doing Business 2007: how to reform. Washington DC: World Bank, International finance corporation. 